\title{
Framing News on Religion and Living Environment in Online Media'
}

\author{
Vanesa Bella Sadmego \\ Communication Science Department - University of Al Azhar Indonesia - Kompleks \\ Masjid Agung Al Azhar, Jl. Sisingamangaraja, South Jakarta, Indonesia - \\ o21-7399510 - vanessabella20@gmail.com
}

\begin{abstract}
Muchammad Nasucha
Communication Science Department - University of Al Azhar Indonesia - Kompleks Masjid Agung Al Azhar, Jl. Sisingamangaraja, South Jakarta, Indonesia
\end{abstract}

\begin{abstract}
In some decades, we have encountered complex and multi-global situation. The crisis has appeared more multifarious, time by time. Some authors and media indicate religion as the crucial factor should be involved to overcome this problem. Media frequently uncover the role of religion in relating environmental crisis. Based on the background, this research aims to find out how the online news media frame religion and the living environment topic. Here, the researchers used framing theoretical conceptual and methods that are adopted from some authors. In this research the news selected by related keywords through search engine. The result shows even though the concern is similar the story or narration are various in presenting the issue of the important stance of religion in dealing with environment. Some nonverbal features used to describe how the story involving the crucial actors and the related event(s).
\end{abstract}

Keywords: religion, living environment, framing analysis, media online

\begin{abstract}
Abstrak. Dalam beberapa dekade, kita menghadapi masalah yang kompleks dan situasi yang multi-global. Krisis yang beragam muncul dari waktu ke waktu. Beberapa pihak dan media menganggap agama sebagai faktor penting terkait masalah ini (krisis global). Media kerap kali memberitakan peran agama terkait masalah atau krisis lingkungan. Berdasarkan latarbelakang tersebut penelitian ini bertujuan untuk mendapatkan bagaimana portal berita online membingkai berita agama dan lingkungan. Peneliti di sini menggunakan teori, konsep, dan metode framing dari beberapa penulis. Berita sebagai data dalam penelitian ini dipilih menggunakan kata kunci terkait melalui mesin pencari (online). Hasil penelitian menunjukkan meskipun terdapat perhatian pada cerita yang serupa, tapi narasi media beragam dalam menghadirkan sikap penting agama dalam menghadapi [isu dan krisis] lingkungan. Beberapa fitur nonverbal digunakan untuk menggambarkan bagaimana cerita melibatkan aktor penting dan peristiwa terkait.
\end{abstract}

Kata Kunci: agama, lingkungan hidup, analisis framing, media daring

1This paper was presented at the 5 th conference on communication, culture and media studies, 14-15 April 2019, Indonesian Islamic University, Yogyakarta, Indonesia 


\section{Introduction}

The earth where we live everyday experiences a lot of pollution and environmental damage that often happens. In this case, we face a serious, complex and also multi-global crisis situation on earth time by time. At the present environmental pollution continues to occur without any action being intervened, including religious people who are considered should to be involved in to overcome it. Basically, religion teaches people to live in harmony with other people and their environment. Religious leaders must understand the religion substantively, which they consider to be a leader to preserve nature and provide prosperity. Especially in the Indonesian context by seeing the crisis of natural destruction worsening, of course the role of religious leaders is needed. Indonesia is synonymous with and identical as the large number of human populations with the Muslim religion in the globe.

Environmental problems that occur on earth today, such as global warming and climate change. There needs to be real action in solving the problem by involving various important parties. This is also in accordance with the target of development in Indonesia, the authority argued in the capital city of DKI Jakarta in 2020, which is towards low emissions development. Seeing these targets, awareness must be developed for the importance of preserving the forest, and the need for communication, information and education related to environmental conservation.

MUI (Indonesian Ulema Council) explained that there had been programs related to sanitation, preservation, and energy, one of which was an eco-mosque program. The program is expected to be emulated by other religious houses of worship (eco-houses of worship). The religious aspect as a guideline for people's lives can be a place for spreading the values of the importance of protecting the environment. In addition, it also needs a real contribution in efforts to realize environmental conservation by forming an interfaith youth environmental movement.

Environmental damage, climate change and global warming are moral issues, environmental crisis is a manifestation of moral crisis. Therefore, overcoming the problem of climate change with all its impacts must be the joint responsibility of all religious communities. Solutions to these environmental damages, including climate change and global warming cannot be handled by one party alone itself, but it is a shared responsibility. It is at this point of collective responsibility that religions find their rendezvous, namely in the value of humanity that religion is revealed to give mercy to humanity. The religious and environmental leaders pressed for a step to inspire all levels of society to start moving to make changes for the sake of environmental sustainability.

Regarding to this case, media as a vital agent hold an important role to give the information to the public. The mass media contribute to the development of related issues while at the same time influencing the formation of public opinion and behavior. It can be said, that the media is not merely as a passive and neutral side, but the media choose certain things to be highlighted, and minimizes other things. The two sides that the media put forward in reporting the news about religion and living environment in online media can lead to diverse interpretations for the audience who consume them. With the emergence of this online media information from an event will very quickly be conveyed by media owners to the public 
through reporting on online media (Romli \& Syamsul, 2012).

Media is known as the vital agent and a means or tools of delivering complete information to the public. In the current era of digitalization, online media has a tremendous penetration of the public.

Media with its platforms conventional and new media- has brought about many consequences to society and human live both positive and negative. McQuail (2000, 2002) has reminded us about the centrality of the media in society. Media produce news as the information and commercial product under some considerations, routines, and other standards and dynamic (Shoemaker \& Reese, 1996). One of the significant media works is media framing. The framing of news direct and provide the way for audience of how to see and understand the topic. It potentials to bring some consequences as what Lippmann said as "picture in our heads". Daniel Kahneman and Amos Tversky stated that media framing of news also can influence on the decision making process phase and result (Littlejohn, Foss, and Oetzel, 2017).

The Internet has leads also the many changes of journalism or media press activities. Flew (2014) stated that journalism or media press activities and products have to adopt internet in almost everything of journalism aspect. He called it as a transformation in news industry: the transforming news and journalism.

As what some or even many authors and researchers said that media has existed as vital factor and agent in society. However, the media only repeat and reinforce what already knew and understood by the audience (Belnaves, Donald, and Shoesmith, 2009; Moenawar, Nasucha, Arianti, 2017), accordingly with this kind of topic (the media role of constructing the news frame of religion and live environment).

When there are natural disasters and even environmental issues in life on earth, a religious perspective is often used. This study aims to find out how online news media frame religion and the environment in the news. In this case religion becomes the main perspective, including about the environment. There are some researches on a combination of religion and environment. However, the research that concerns about how the media framing the issue (religion and environment) is still recurrently neglected.

Based on the result search of "Berita Tentang Agama dan Lingkungan" this research found that 26.400.00o related result on the internet that consider as news. New media is a kind of channel which is the content is very dynamic. We can find the fluctuation and changes in this such media. For example, the search on different slightly minute in this case designate and bring us to the different result, may increase or decrease the result. In this case the result in the next search was (24.500.000) decrease (see figure.1).

\section{Method}

This research is based on the constructivist paradigm dominantly in qualitative (Guba, 1990; Patton, 2002). The paradigm assumes that reality is socially meaning constructed, in this research is the news frame by the media. The data were collected using online document study, and purposive judgment sampling applied (Patton, 2002; Neuman, 2014) based on the emerging news category. The data source of this research is the published news in online media. Technically, the news was chosen using the Google search engine with the keyword "Berita Tentang Agama dan 
Lingkungan", dan "Berita Tentang Lingkungan dan Agama" starting from the first layer that appeared on Google search pages to the tenth.

The analytical method used qualitative framing derived from framing concept combination of Robert N. Entman, Murray Edelman, William A. Gamson, Zhongdang Pan \& Gerald M. Kosicki. The mere application of a frame should promote a certain interpretation, problem definition, and causal relationships. (Eriyanto, 2002; Entman, 2004).

The frame manifests itself in media content through various framing devices, such as word choice, metaphors, exemplars, descriptions, arguments, and visual images (Gamson \& Lasch, 1983; Pan \& Kosicki, 1993) as the narration or the way of telling a story of religion and environmental issue. It could consist of various textual features of the story headlines, audio-visual components, metaphors used, and the way in which the story is told, to name only a few of the ways framing function (Littlejohn, Foss, and Oetzel, 2017).

Framing analysis is an analysis used to see how the media construct reality, in this research is the relation of religion and environmental. This analysis is also used to see how to read and be framed by the media (Eriyanto, 2002). Framing is defined as the process of making a message stand out, placing more information than others so that the audience is more focused on the message. Basically, framing analysis is the latest version of the discourse analysis approach, specifically for analyzing media texts. The idea of framing was first put forward by Beterson in 1995 . At first framing was interpreted as a conceptual structure or set of beliefs that organized political views, policies, and discourses and which provided the discourse of standard categories to appreciate reality (Sobur, 2002).

In other words, framing is an approach to find out how the perspectives that journalists use when selecting issues, writing and presenting about anything in and through news (Sobur, 2006). According to Abrar there are at least three news sections that can be the object of a journalist's frame, namely: the headline, the focus of the news, and the closing news. Then, the focus of the news is the framing with associative techniques, which is combining the actual policy with the focus of the news. Framing analysis methods can be done with a variety of focus and objectives, it because this is related to various definitions and scope of framing itself which is quite complex as what Shoemaker and Reese (1996), McQuail $(2000,2002)$ or other authors of media studies have stated about.

This study also combines the Robert N. Entman framing analysis method with four tools, namely: Define Problems, Diagnose Cause, Make Moral Judgment, and Treatment Recommendation by emphasizing the prominence of the frame of mind, perspective, and concepts about interpreting news.

In operating the analysis of framing used in this study, there are four structural dimensions of the news text as a framing device, namely: syntax, script, thematic and rhetorical. The frame is an idea that is associated with different elements in the news text, the source, background information, the use of certain words or sentences into the text as a whole. Frames relate to meaning. How someone interprets an event, can be seen from the set of signs that appear in the text.

The syntactic structure can be observed from the news chart. Syntax deals with how journalists arrange events, 
statements, opinions, quotes, observations of events into the form of news stories. Thus the syntactical structure can be observed from the news chart (selected headlines, leads used, background information to be relied on, sources cited and so on). The script structure looks at how the storytelling strategy. This structure sees the speaking style that journalists use in packaging events. Thematic structure relates to the way a journalist expresses his view of events into propositions, sentences, or relationships between sentences that make up the text as a whole. This structure will show how that understanding is translated into smaller forms. While the rhetorical structure is related to the way the reporter stresses certain meanings. In other words, the rhetorical structure of seeing the use of words, idioms, graphics, images used for emphasizing certain meanings.

\section{Result and Discussion}

News, also on internet (portal media or online news) structure and display constructs of events or topics as general news in other media, using visual, verbal and nonverbal communication according to the provided platform. Telling the story by the language, whether in formal or informal structures, also use images and picture as supporting elements of a frame, some complimentary, or other according to direct and lead audience to the goals of news (see figure 2)

Since many news about religion and the environment in online media during 2013 until 2019, 25 news was selected and considered in accordance with this study. Based on the results of the framing of religion and environmental news conducted, it can be seen from the news headline entitled the news coverage in online media is for the role and involvement of religious leaders to address environmental issues. From the selected news we can find the title of the news that needs to be considered about the actions taken from religious leaders on environmental issues being processed.

The highlighted topic in the scope of the problem is about the existence of damage and destruction of nature by humans. Religion painstakingly deliberates causes of the destructions as very influential effort to guide the actions through actors. The actors here means, including religious leaders, communities, surrounding communities or society (social environment), interfaith, and others. Based on the news that has been selected for framing analysis, the cause of the problem encountered is human behavior that has an impact on nature. It was found that humans often view nature as an object, not a soulful subject. Humans get a mandate to protect nature and environmental problems caused by mental human beings. It is considered religious leaders can influence humans with a religious side approach such as moral approaches and religious ethics, religious teachings on how to preserve the environment accordingly.

Each of these frames can also be applied to cover different events and topics (Berns, 2004). Framing includes elements of the problem, causes of problems, visual images, moral judgment, and recommendations for problem solving. The element of the scope of the dominant problem with the issue of environmental damage is the concern of many figures so that's necessary to preserve the environment through a spirituality or religious approach. The cause of the problem is the damage and environmental crisis today happened caused by humans perceive nature as an object rather than a soulful subject as what presented by online news such as https://www.bbc.com, https://nasional.sindonews.com, https:// 
antaranews.com, www.voaindonesia.com, and others. Generally, there is a picture in the news, out of 25 news items framing, the majority of the images that appear are pictures of the General Chairperson of the Muhammadiyah Political Organization, Din Syamsuddin.

From the 25 selected-news we can find the displayed images were varied and it turned out that it determined how the contents of the news presented, there were news with images of Din Syamsuddin as general chairman of Muhammadiyah Political Organization, and things that included nature to supporting visualization that indicated every variety of religions needed to protect the environment. For example, one news with a displayed image of Din Syamsuddin, as the general chairman of Muhammadiyah Political Organization, will provide a series of news that including a recently happened phenomenon of nature, and persuade readers to increase their sense of belonging to nature by reference to holy Quran verses.

The collage images on figure 2, picture of Din Syamsuddin as the general chairman of Muhammadiyah Political Organization, is the picture that appeared the total of the 3 news that have been selected in media online, and most of those pictures appeared at the header of the news. From the 25 selected-news, a few of news had a picture that also appears at the header, and a few more had a picture that appears in the middle of the news. The selected-news appearing in this research that show religious figures were dominated by the figure of Din Syamsuddin, could be a supporting element of the news. That's a make sense because the figure could be increasing awareness and herding public opinion. General chairman of Muhammadiyah Political Organization, Din Syamsuddin, famous for his moment as a more famous religious figure talking about ecology.

Each image that appeared on every news could be a strengthened a news when it becomes a unity between the title and the news. Besides that, image can be also a complementary, so it can develop people's imagination with these images. The image can be an attribute, attribute here means if it doesn't appear, it could decrease the identity of the title even of the news. The last, image also can be an ornament that could make a news looks show. The images of Din Syamsuddin appeared on the 3 media online is Sindonews, Antara, and Hidayatullah. Only Antara write the title without the name of Din Syamsuddin, so it can be said Antara have an assumption that people who read that kind of news already have knew the figure of Din Syamsuddin.

The moral judgment is dominated by depiction and catchphrase. Several depictions found that told about quotation from holy Quran verses, as a reference that the command to preserve nature has been explained in the holy Quran. Besides, there's also a quotation from some actors in the news such as quotation from the Ministry of Religion of the Republic of Indonesia, general chairman of Muhammadiyah organization, priest, Hindu lecturer. Additionally, the moral judgment, consists of sub-framing elements such as a catchphrase that tend to increase awareness as a human being to be a "protector of God's creation" and "a prevention is worth than a pound of cure". Islam told in the holy Quran verses consciously talking about humans have an obligation to manage nature, so they are not allowed to destroy nature. If a religious person is the highest end of the God, then he must obey orders.

The depiction of moral judgment aspects also tends to be a lot. Few of news mentioned a holy Quran verses as a 
reference that environmental conservation must be applied in everyday life as a human being. Eventually, the solving recommendation is most of people in this world have their own religion, so religious leaders plays an important role here in addition to providing a preaching to citizens about the relationship of living side by side with nature. Religious-leaders' roles here can also pressure the government, both central and regional, to be smart in managing nature. Lexical aspects that appeared in the news such as leaders of religion, public, Islamic or Muslim, youth community across religion emerged in scope of the problem and also problem recommendation elements. Besides, the choice of words such as characters and figures still used to distinguish between the two figures.

This research uses framing method in an unusual method and rare way to frame. The tools used in this study are a combination of framing methods introduced by four characters (Robert N. Entman, Murray Edelman, William A. Gamson, Zhongdang Pan \& Gerald M. Kosicki). Using such as this framing device, it turned out that when explaining the scope of the problem, what appeared was syntax and script elements to describe how the problem situation existed. The syntax is how the media compiles facts, while the script elements are how a media presents facts. Whereas a text inevitably contains elements that are incongruent with the dominant frame, the frame has the effect of making elements that are congruent more salient, so that the receiver is more likely to notice them (Eriyanto, 2002; Entman, 1991).

When it moved to cause of the problem, what shown the most are syntax, script, and also roots. As it described above, the syntax is about how the media compiles facts, the script, including elements are how a media presents facts in detail such as when, where, why, what, who and how, and also roots are caused. About the visual images displayed in the framed media, only syntax that appeared, it because of the description of syntax has compiled the facts. Visual images are a supporting element(s) such as relevant images and graphics. But most of visual images appeared here, is an image of the General Chairperson of the Muhammadiyah Political Organization, one of the biggest religion organization in Indonesia, Din Syamsuddin and following by the image of green forest, Indonesian maps, and so on.

When explaining the moral judgment, an element that performed the most are depicted, catchphrase, and syntax. The depiction is depicting a connotative issue, in the form of vocabulary to make a label on something. The catchphrase is about interesting phrases, contrasts in a discourse, usually in the form of jargon. And syntax is about how the media compiles facts. In the end, when explaining the problem-solving recommendations, the only one element that appeared is syntax. This thing is same as visual image element. Eventually, after summarizing all the tools framing elements used, it was found that more detail was that the syntax elements could be found in every tool. It because of syntax provides a fact.

The last is about problem solving recommendations. The result turned out after the news processed. Overall, there are some actions that humans must take on nature, including increasing each other awareness for being good to nature, apply what has been written in the holy Quran, preach on environmental issues, establish religious values. Moreover, the religious approach to protecting the environment is contemplated also very important. The implementation of that is making the collaboration between religion and government by involving the role of clerics, and religious leaders. 
It seems in line with some previous researches results and findings, for instance a study by Zakiyah (2015) focusing on religious approach in bearing with social problem, and also the research by Zainuddin (2011) under the title "Religion and environment into the direction of establishing ethical-ecological behavior to develop green-ecology" that focusing only on how religion and environment must be handled, not about how media frame those specific issue.

The framing devices proposed by each character are different in terms of the elements, there are advantages and disadvantages of each device. In one device, there are things that can be obtained by other character's tools, some of which cannot be obtained. Based on the advantages and disadvantages that the authors found, so that's the background why the author is tend to choose using the framing devices which has been introduced by the four actors and combined.

From the table 1, it could be found that the news in the media online with the title that leads to religion role to keep the environment occupying a dominant or majority position with total frequency 11 and the total percentage is $44 \%$. The number two position is occupied by the title of news that leads to religious issues as the subject of discussion with total frequency 8 and the percentage total is $32 \%$. Next, is about involvement of religious leaders in protecting the environment with total frequency 4 and the total percentage is $16 \%$. The last, the news in the media online with the title that leads to religion and environment issues from community perspectives with total frequency 2 and the total percentage is $8 \%$.

The advantages of the framing method introduced by Gamson and Modigliani include the most elements than the similarities with other figures, but unfortunately in this method there is no recommended effective solution. The method introduced from Zhongdang and Kosicki is also quite complete because it packs facts with added visual elements and emphasizes certain issues. Compared to elemental similarities than other figures, Edelman only provides elements starting from what the scope of the problem is, and how to define specifically about the problem, until effective solutions are recommended to package the problem. The disadvantage of this method is that the specific packaging about handling the issue is lacking. For the Entman method, the similarities that found with others are only 3 elements starting from how the issue can be understood and the existence of an argument on defining the last made problem is how the solution is offered to overcome the problem. 
Vanesa Bella Sadmego \& Muchammad Nasucha, Framing News on Religion and Living Environment in Online Media

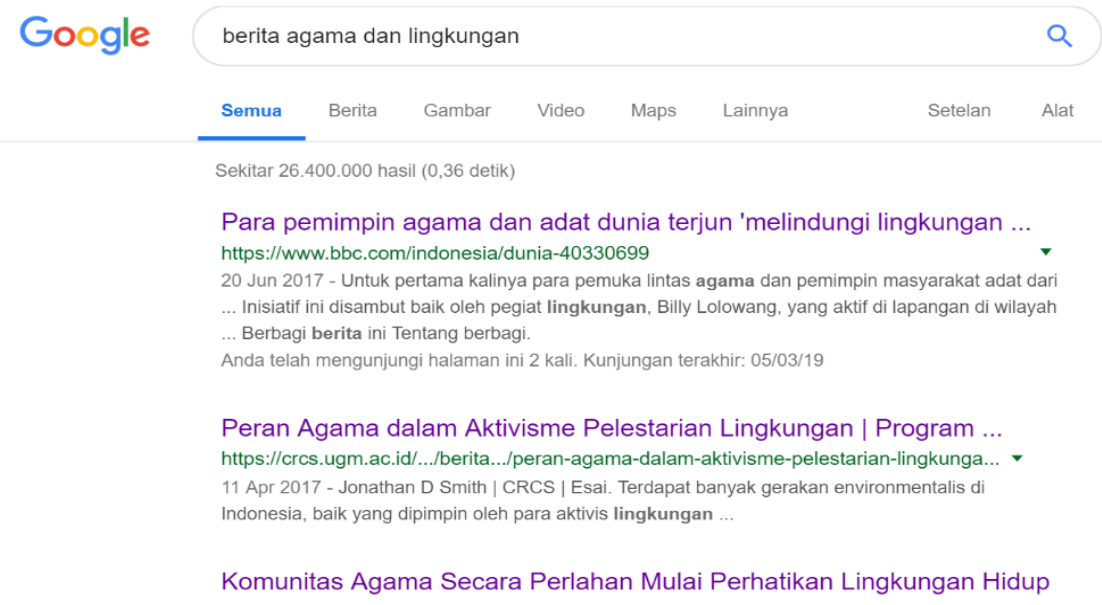

Figure 1. Sorting news in online media with keyword "Berita Agama dan Lingkungan"

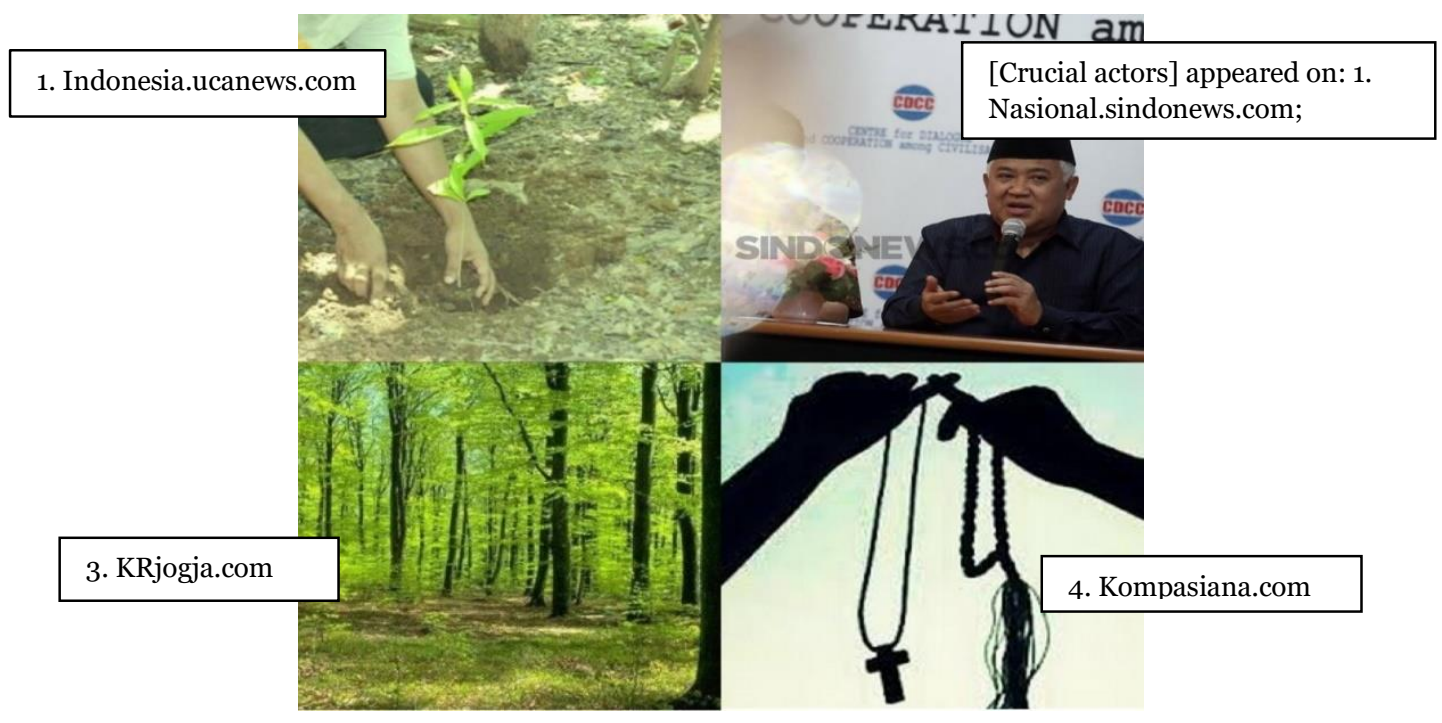

Figure 2. Visual images in a few news with the keyword "Berita Agama dan Lingkungan"

Table 1. Relation of religion and environment in news media online

\begin{tabular}{lcc}
\hline \multicolumn{1}{c}{ Title } & Frequency & Percentage \\
\hline $\begin{array}{l}\text { Involvement of religious leaders in } \\
\text { protecting the environment }\end{array}$ & 4 & $16 \%$ \\
$\begin{array}{l}\text { Religion role to keep the } \\
\text { environment }\end{array}$ & $\mathbf{1 1}$ & $\mathbf{4 4} \%$ \\
$\begin{array}{l}\text { Religious issues as the subject of } \\
\text { discussion }\end{array}$ & 8 & $32 \%$ \\
$\begin{array}{l}\text { Religion and environment issues } \\
\text { from community perspectives }\end{array}$ & 2 & $8 \%$ \\
\hline \multicolumn{1}{c}{ Total } & $\mathbf{2 5}$ & $\mathbf{1 0 0} \%$ \\
\hline
\end{tabular}




\section{Conclusion}

The conclusion of this research based on the data (news in media online) found that the environmental conservation that have been an important issue to face, so the roles of religious leaders were needed here as the frame of media. Other, religious leaders play the main role, they could and very potential to be an opinion leader(s) to bring the public opinion of the citizens to keep this nature properly. The results show that the concern is similar the story or narration are various in presenting issue of important stance of religion in dealing with environment, in this research are four topic or such kinds of title of news: (1) Involvement of religious leaders in protecting the environment, (2) Religion role to keep the environment, (3) Religious issues as the subject of discussion, (4) Religion and environment issues from community perspectives.

Some nonverbal features and even displayed images used to describe how the story involving the crucial actors, and the related event. Sometimes, the visual elements also determine how the news in media online is presented and also bring around the key word on the Google search. It figured it out that, news dominated with the figure of the Islamic leader in Indonesia (related country) could herding public opinion and determine the news sequence. The scope of the problem element including syntax and script, the metaphor also including the depiction and catchphrase, other elements determined by how does the news arranging the news titles.

Related to the spread of news about the framing of religion and living environment on social media, various parties such as law enforcement, government, ministries, religious leaders and related institutions should make efforts to be responsive and quick to take concrete steps in handling living environment cases in Indonesia, in terms of this specifically refers to religion leaders must understand religion itself substantively.

The government needs to develop strong steps and strategies, so that the problem of the natural environment in Indonesia is quickly resolved. Besides the decisive action from the government and religious leaders, besides that parents and the community are also encouraged to always be vigilant in accessing the internet.

The media as a means of delivering messages, must still pay attention to objectivity in conveying news by displaying news in accordance with the facts. The public needs further education to be more observant in interpreting any information contained in a news. The information presented may occur because it is the result of construction from journalists and does not match the actual reality. The influence received by the media sometimes causes unrest from the public. 


\section{Reference}

Sobur, Alex (2002). Analisis teks media: Suatu pengantar untuk analisis wacana, analisis dan framing. Bandung: PT Remaja Rosdakarya.

Sobur, Alex. (2006). Semiotika komunikasi. Bandung: Remaja Rosdakarya.

Balnaves, Mark., Stephanie Hemelryk Donald \& Brian Shoesmith. (2009). Media theories \& approaches: A global perspective. London, New York: PalgraveMacMillan.

Eriyanto. (2002). Analisis framing; konstruksi, ideologi, dan politik media. Yogyakarta: LKIS.

Flew, Terry. (2014). New media. Oxford: Oxford University Press.

Griffin, Em., Ledbetter, Andrew., Sparks, Glenn. (2015). A first look at communication theory, (ninth edition). McGraw Hill, New York.

Gorp, Baldwin Van. (2007). The constructionist approach to framing: bringing culture back in. Journal of Communication 57 (2007) 60-78, 2007 International Communication Association.

Guba, Egon G. (Ed.). (1990). The paradigm dialog. Newbury Park: Sage Publications.

Littlejohn, Stephen W., Karen A. Foss, John G Oetzel. (2017). Theories of human communication, (eleventh edition). Waveland, United States of America.
Miller, Katherine. (2005). Communication theories; perspectives, processes, and contexts, (Second edition). McGraw Hill, Boston.

McQuail, Denis. (2000). McQuail's mass communication theory. $\quad 4^{\text {th }}$ Edition). London: Sage.

McQuail, Denis. (ed). (2002). McQuail's reader in mass communication theory. London: Sage.

Moenawar, M. Ghozali., Nasucha, Muchammad., \& Arianti, Gusmia. (2017). Media komunikasi: Diskursus profetik, agama, dan pembangunan. Jakarta: UAI Press.

Neuman, W. Lawrence. (2014). Social research methods: Qualitative and quantitative approaches. (Seventh edition). Boston: Pearson.

Patton, Michael Quinn. (2002). Qualitative research \& evaluation methods (third edition). Thousand Oaks: Sage publications.

Romli, A.S.M. \& A Syamsul. (2012). Jurnalistik online: Panduan praktis mengelola media online. Bandung: Nuansa Cendekia.

Scheufele, Dietram A. (1999). Framing as a theory of media effects. Journal of Communication, Winter.

Shoemaker, J. Pamela., and Reese, Stephen D. (1996). Mediating the message: Theories of influences on mass media content. New York: Longman. 
Jurnal komunikasi, Volume 14, Nomor 1, Oktober 2019, Hal 93-104 